\title{
Cox-2 inhibition activities of creams containing Anguilla bicolor and sea cucumbers extract on croton oil induced inflammation in mice
}

\author{
Heru Sasongko ${ }^{1,2 *}$, Waliyyin Razan Qanit ${ }^{1}$, Raka Sukmabayu Weninggalih Sugiantoro ${ }^{1}$, \\ Agung Putu Surya Purna Kristyawan ${ }^{1}$,Dian Eka Ermawati ${ }^{2}$, Wisnu Kundarto ${ }^{2}$, \\ Nining Sugihartini ${ }^{3}$ \\ ${ }^{1}$ Department of Pharmacy Faculty of Mathematics and Natural Sciences, \\ Universitas Sebelas Maret Surakarta \\ Jl.Ir Sutami No 36A Kentingan Surakarta, Central Java, Indonesia \\ ${ }^{2}$ Department of Diploma 3 Pharmacy, Sekolah Vokasi Universitas Sebelas Maret Surakarta \\ Jl. Kolonel Sutarto No150K, Jebres, Surakarta City, Central Java 57126, Indonesia \\ ${ }^{3}$ Faculty of Pharmacy Universitas Ahmad Dahlan Yogyakarta \\ Jl.Prof.Dr. Soepomo, Janturan, Yogyakarta, Indonesia
}

\begin{abstract}
The fatty acids, like EPA and DHA, were known as anti-inflammation. It works on inflammatory tissue, brought by edema plasma, and changed into resolvins, protectins, and maresins by the enzyme reaction. Anguilla bicolor and Sea cucumber fish are known to contain EPA and DHA. This study analyzes the inhibition Cox-2 effect of the combination of Anguilla bicolor oil with sea cucumber extract as an active ingredient in a cream preparation. This experiment used 7 groups of male BALB/C strain mice: normal control; negative control; positive control; A. bicolor oil cream; $H$. leucospilota extract cream; a combination of A. bicolor : H. leucospilota (2:1) cream; a combination of A. bicolor : H. leucospilota $(1: 2)$ cream. The anti-inflammatory activity was evaluated by the amount of inflammatory cell, the thickness epidermis, and the amount of cell expression COX-2 on mice's back skin tissue induced by croton oil $(0,1 \%)$. After 3 days, histopathological skin tissues were made. The data were analyzed statistically by One Way ANOVA followed by LSD to know each group's differences at a significance level of 0.05 . The experiment results showed that the formula with the best anti-inflammatory activities is the combination of A. bicolor and $H$. leucospilota (2:1) cream. The decrease of the amount of inflammatory cell $(75.97 \%)$, the thickness of the epidermis $(43.88 \%)$, and the amount of COX-2 cell expressions (60.52\%) from the formula did not differ significantly with the positive control $(\mathrm{p}>0,05)$. It can be concluded that A. bicolor and $H$. leucospilota have antiinflammation activity based on the experiment results.
\end{abstract}

Keywords: Anti-inflammatory, Anguilla bicolor, Cox-2, sea cucumber

\footnotetext{
*Corresponding author:

Heru Sasongko

Department of Pharmacy, Universitas Sebelas Maret

J1 Ir Sutami No 36A Kentingan Surakarta, Central Java, Indonesia

Email: heru_sasongko@staff.uns.ac.id
} 


\section{INTRODUCTION}

Docosahexaenoic acid (DHA) and Eicosapentaenoic acid (EPA) are unsaturated fatty acids of the omega-3 variant that are commonly found in fish oil (Calder, 2013). Both compounds are known to have inflammatory activity (Mullen et al., 2010). DHA and EPA work by regulating gene expression that causes a decrease in inflammatory mediators such as Tumor Necrosis Factor-alpha (TNF- $\alpha$ ), Interleukin-1b, VCAM-1, and ICAM-1 (Vors et al., 2017). DHA and EPA fatty acids are found in eel (Anguilla bicolor) (Kusharto et al., 2014) and sea cucumber (Wen et al., 2010). Eel (Anguilla bicolor) is a fish often found in many countries, including Indonesia, Japan, Italy, China, and France (Ahn et al., 2015). However, this fish has not been fully utilized in Indonesia, which can be seen from the public's low consumption of eels (Sasongko et al., 2018). Likewise, around 350 types of sea cucumber are found in Indonesia, making it the biggest producer of sea cucumbers in the world (Lane and Limbong, 2015; Purwati, 2018).

Eels contain EPA and DHA as many as $1.15 \%$ and $5.16 \%$, respectively (Kusharto et al., 2014). Omega 3, especially EPA and DHA in sea cucumbers, is $0.22 \mathrm{mg} / \mathrm{mL}$ (Yahyav, 2012). This amount is classified as high so that eels and sea cucumbers have potential activity as an anti-inflammatory. It can be known from previous research that giving ointments containing eel oil can speed up the healing process of a cut wound (Sasongko et al., 2018). It is suspected that the healing process can speed up due to the anti-inflammatory activity of eel oil. Meanwhile, the sea cucumbers extract with $150 \mathrm{mg} / \mathrm{kg}$ dose can produce anti-inflammatory activity equivalent to aspirin (Whitehouse and Fairlie, 1994). Because of its activity as an anti-inflammatory, sea cucumber extract is also known as a potential anticancer agent (Janakiram et al., 2015).

Some described studies have shown the potency of eel and sea cucumber as an oral antiinflammatory (Sasongko et al., 2019). The conducted study investigates the anti-inflammatory activity of a combination of sea cucumber extract and eel oil in topical preparations. Tests were carried out on mice induced with croton oil, an irritating agent in cosmetics development (Kitajima et al., 2018). Anti-inflammatory activity was measured by the inhibition percentage of cyclooxygenase (COX-2), decreased inflammatory cells, and epidermal thickness as parameters. COX-2 is an enzyme that acts as a pain-inducing mediator in cells experiencing inflammation (Moore and Simmons, 2012). COX-2 is typically not present in the tissue and will be formed when cells experience inflammation. Inhibition of the COX-2 enzyme will disrupt the conversion of arachidonic acid into prostaglandins (Garavito and Dewitt, 1999). This conversion's inhibition disrupts the migration process from neutrophils to macrophages, disrupting cytokine secretion, and decreasing inflammatory cells' distribution. Prostaglandins' action causes edema to form, which can be seen through the thickening of the epidermal tissue in the injured skin (MacKay and Miller, 2003).

\section{MATERIALS AND METHOD}

\section{Materials}

Materials used in the research are: sea cucumbers (Holothuroidea leucospilota), each weighed around 100-200 grams, obtained from fishermen at Soge beach, Pacitan; eels obtained from Unagi Universitas Sebelas Maret livestock with each fish weighed around 200-300 grams, and methanol (Merck). Meanwhile, materials used in making cream preparations are: stearate acid (Merck), liquid paraffin (Merck), triethanolamine (Merck), lanolin (CV. Pharmalab), methylparaben (Sigma-Aldrich), and virgin oil coconut (VCO). The tools used are a set of reflux devices (Pyrex), a rotary evaporator (STUART® RE300), a microscope (Olympus CX31), and an optilab (Advance Plus). 


\section{Methods}

\section{Preparation of test animals}

A total of 28 adult male Balb-c mice with weigh around 25-30 g were acclimatized for 7 days before the treatment started. Mice were kept in insulated $50 \times 80 \mathrm{~cm}$ plastic cages (one cage containing 4 animals) with ad libitum feeding and drinking, and 12 hours light-dark cycle. All test animal handling procedures have received approval from the ethics committee of Universitas Sebelas Maret with letter number 524/IV/HREC/2018.

\section{Producing eel fish oil extract}

Eels that have been cleaned from the stomach, mucus, and blood, were extracted using the reflux method at a temperature of $70-80^{\circ} \mathrm{C}$ with distilled water. The oily phase (at the top side) was taken with a sterile pipette and filtered with Whatman paper after leaving the reflux for 24 hours. The obtained oil was stored in a closed container (Sasongko et al., 2017).

\section{Producing sea cucumber extract}

Sea cucumbers that have been washed and their stomach cleaned, were cut into smaller pieces to be dried. Sea cucumber extract was obtained through the maceration method with methanol as a solvent, then thickened with a rotary evaporator at a temperature of $30-40^{\circ} \mathrm{C}$ and evaporated so that the dry sea cucumber extract was obtained (Wiranto et al., 2016).

\section{Cream preparations}

Cream preparation was done based on the modification of the research by Sugihartini et al. (2017). The cream preparation made of sea cucumber and eel was made by the melting method. It started with melting the water-soluble ingredients (mixture A) on the water bath at $75^{\circ} \mathrm{C}$. Those ingredients are: aqua dest, triethanolamine, and methylparaben. The oil-soluble ingredients are then melted at the same temperature. Those ingredients are: stearate acid, liquid paraffin, lanolin, eel fish oil, and virgin coconut oil (VCO). The melted A and B mixtures were mixed in a warm mortar and then continuously stirred until a homogeneous cream phase was formed. Sea cucumber extract was added after the cream phase had formed. The cream formula can be seen on the matrix in Table 1.

Table 1. The formula of eel fish oil and sea cucumber extract cream

\begin{tabular}{lccccc}
\hline \multicolumn{1}{c}{ Ingredient } & $\mathbf{F 1}$ & $\mathbf{F 2}$ & $\mathbf{F 3}$ & $\mathbf{F 4}$ & F5 \\
\hline Eel Fish Oil & - & $1 \mathrm{~g}$ & - & $0.7 \mathrm{~g}$ & $0.3 \mathrm{~g}$ \\
Sea Cucumber & - & - & $1 \mathrm{~g}$ & $0.3 \mathrm{~g}$ & $0.7 \mathrm{~g}$ \\
Extract & $2.5 \mathrm{~g}$ & $2.5 \mathrm{~g}$ & $2.5 \mathrm{~g}$ & $2.5 \mathrm{~g}$ & $2.5 \mathrm{~g}$ \\
Liquid Paraffin & $7.25 \mathrm{~g}$ & $7.25 \mathrm{~g}$ & $7.25 \mathrm{~g}$ & $7.25 \mathrm{~g}$ & $7.25 \mathrm{~g}$ \\
Stearate Acid & $0,75 \mathrm{~g}$ & $0.75 \mathrm{~g}$ & $0.75 \mathrm{~g}$ & $0.75 \mathrm{~g}$ & $0.75 \mathrm{~g}$ \\
TEA & $1.5 \mathrm{~g}$ & $1.5 \mathrm{~g}$ & $1.5 \mathrm{~g}$ & $1.5 \mathrm{~g}$ & $1.5 \mathrm{~g}$ \\
Lanolin & $10 \mathrm{ml}$ & $10 \mathrm{ml}$ & $10 \mathrm{ml}$ & $10 \mathrm{ml}$ & $10 \mathrm{ml}$ \\
VCO & $0.025 \mathrm{~g}$ & $0.025 \mathrm{~g}$ & $0.025 \mathrm{~g}$ & $0.025 \mathrm{~g}$ & $0.025 \mathrm{~g}$ \\
Nipagin & $\mathrm{ad} 50 \mathrm{~g}$ & $\mathrm{ad} 50 \mathrm{~g}$ & $\mathrm{ad} 50 \mathrm{~g}$ & $\mathrm{ad} 50 \mathrm{~g}$ & $\mathrm{ad} 50 \mathrm{~g}$ \\
Aqua dest & & & & & \\
\hline
\end{tabular}

\section{Anti-inflammatory activity test}

The determination used a modified method of (Sugihartini et al., 2017). The research used 7 treatment groups, with each group consists of 4 mice. The seven treatment groups were normal control groups that did not get any treatment at all, and the rest were given inflammation induction with croton oil. The rest six groups with the induction were given different treatments: cream base (F1); sodium 
diclofenac gel (positive control); eel fish oil cream (F2); sea cucumber extract cream (F3); cream containing eel fish oil and sea cucumber extract $(2: 1)(\mathrm{F} 4)$; cream containing eel fish oil and sea cucumber extract (1:2) (F5), and no preparation treatment given (negative control).

The groups of mice that received inflammation induction previously had their dorsal hair shaved and smeared with a hair stripper. After 24 hours, $0.1 \mathrm{ml}$ of croton oil (4\%) was put on their back. After 30 minutes, it was rubbed with preparations according to the treatment every day for 3 days. Then, the mice were euthanized using the cervical dislocation method. The skin tissue was then taken and immersed in $10 \%$ formalin to make histopathological preparations using hematoxylin-eosin (HE) and immunohistochemical stainings for COX-2. Anti-inflammatory test indicators can be seen by comparing the number of inflammatory cells, epidermal thickness, and the number of cells expressing COX-2 in the normal group with six treatment groups. The number of inflammatory cells can be seen through the dark brown spots seen from the histopathological preparations stained with HE. The epidermis thickness is measured from the average distance of the outer to the deepest epidermal layer. The number of cells expressing COX-2 was indicated by the number of cells with brown-colored cytoplasm or nucleus. The observation was carried out using a microscope connected to an optilab camera with 400 times magnification (Sugihartini et al., 2017).

\section{Data Analysis and Statistics}

The percentage of the number of cells expressing COX-2 was calculated by the following equation (Sugihartini et al., 2017) :

$$
\% \text { Expression }=(\text { Number of expressed cells } / \text { Total number of cells }) \times 100 \%
$$

Statistical analysis was conducted to calculate the percentage of cells expressing COX-2, epidermis thickness, and the number of inflammatory cells on treatment groups to control groups. The differences between each group were evaluated using One Way ANOVA. If a significant difference was found, it would be analyzed further using the Post Hoc LSD test to see the difference among treatment groups. The significance result is determined with the critical P-value $(\mathrm{p}<0.05)$.

\section{RESULT AND DISCUSSION}

The data results of anti-inflammatory tests with inflammatory cells, epidermal thickness, and the number of cells expressing COX-2 as parameters are shown in Table 2.

Table 2. Anti-inflammatory test results of creams containing eel fish oil and sea cucumber extract in BALB/C mice induced with croton oil

\begin{tabular}{|c|c|c|c|}
\hline Groups & $\begin{array}{c}\text { Thickness of } \\
\text { Epidermis }(\mu \mathrm{m})\end{array}$ & $\begin{array}{c}\text { Number of } \\
\text { Inflammatory } \\
\text { Cells }\end{array}$ & $\begin{array}{c}\text { Number of Cells } \\
\text { Expressing COX- } \\
2(\%)\end{array}$ \\
\hline Normal Group & $16.29 \pm 1.289^{\mathrm{a}, \mathrm{b}}$ & $16.33 \pm 2.906^{\mathrm{a}, \mathrm{b}}$ & $19.89 \pm 1.388^{a \cdot b}$ \\
\hline Negative Control & $51.06 \pm 4.201$ & $77.33 \pm 6.009$ & $67.56 \pm 6.194$ \\
\hline Positive Control & $32.15 \pm 1.280^{\mathrm{a}}$ & $17.11 \pm 5.481^{\mathrm{a}, \mathrm{b}}$ & $22.11 \pm 0.314^{a . b}$ \\
\hline Eel Fish Oil Cream & $30.07 \pm 7.156^{\mathrm{a}, \mathrm{b}}$ & $23.19 \pm 5.215^{\mathrm{a}, \mathrm{b}}$ & $44.22 \pm 1.750^{a . b}$ \\
\hline Sea Cucumber Extract Cream & $33.18 \pm 4.380^{\mathrm{a}, \mathrm{b}}$ & $26.81 \pm 3.548^{a, b}$ & $46.78 \pm 4.166^{a . b}$ \\
\hline $\begin{array}{l}\text { Cream Containing Eel Fish Oil }+ \\
\text { Sea Cucumber Extract }(2: 1)\end{array}$ & $28.66 \pm 6.793^{\mathrm{a}, \mathrm{b}}$ & $18.58 \pm 1.816^{\mathrm{a}, \mathrm{b}}$ & $26.67 \pm 2.082^{a . b}$ \\
\hline $\begin{array}{l}\text { Cream Containing Eel Fish Oil }+ \\
\text { Sea Cucumber Extract }(1: 2)\end{array}$ & $36.35 \pm 10.330^{\mathrm{a}, \mathrm{b}}$ & $23.53 \pm 1.042^{\mathrm{a}, \mathrm{b}}$ & $31.33 \pm 2.494^{a . b}$ \\
\hline
\end{tabular}


Mice in the negative control group had the most epidermal thickness, inflammatory cells, and cells expressing COX-2 compared to all groups. This shows that croton oil has irritant properties and can act as an inductor of inflammation (Lan et al., 2012). The mechanism of croton oil is by activating phospholipase A2 then removing arachidonic acid from the cell membrane. The released arachidonic acid is then metabolized into prostaglandins and leukotrienes (Shah et al., 2011). The decreased number of inflammatory cells, epidermal thickness, and cells expressing COX-2 showed significant differences compared to all treatment groups based on the statistical analysis. In the negative control group, it can be seen that the cream base used does not have anti-inflammatory activity. The number of inflammatory cells, epidermal thickness, and the number of cells expressing COX-2 in negative controls were then used as comparisons to determine the percentage of reduction in the number of inflammatory cells and the decrease in epidermal thickness, which can be seen in Table 3.

Table 3. Percentage of anti-inflammatory cells number, epidermis thickness, and COX-2 expression in all groups

\begin{tabular}{lccc}
\hline \multicolumn{1}{c}{ Groups } & $\begin{array}{c}\text { Number of Anti- } \\
\text { inflammatory } \\
\text { Cells (\%) }\end{array}$ & $\begin{array}{c}\text { Epidermis } \\
\text { Thickness (\%) }\end{array}$ & $\begin{array}{c}\text { Number of Cells } \\
\text { Expressing COX-2 }\end{array}$ \\
\hline Positive Control & $77.87 \pm 7.087$ & $37.03 \pm 2.507$ & $69.40 \pm 1.527$ \\
Eel Fish Oil Cream & $70.01 \pm 6.744$ & $41.12 \pm 14.720$ & $34.54 \pm 2.144$ \\
Sea Cucumber Extract Cream & $65.34 \pm 4.588$ & $35.05 \pm 8.578$ & $30.75 \pm 5.103$ \\
Cream Containing Eel Fish Oil & $75.97 \pm 2.349$ & $43.88 \pm 13.304$ & $60.52 \pm 0.093$ \\
+ Sea Cucumber Extract (2:1) & & & $53.62 \pm 3.055$ \\
Cream Containing Eel Fish Oil & $69.57 \pm 1.347$ & $28.82 \pm 20.231$ & 5 \\
+ Sea Cucumber Extract (1:2) & & & \\
\hline
\end{tabular}

All treatment groups had a significant difference when compared to the negative control ( $p$ $<0.05)$ and had no significant difference with the positive control group ( $p>0.05)$ based on the statistical test result. This shows that all creams made of eel and sea cucumber oil as active substances have anti-inflammatory effects. In Figure 1, an example of microscopic observation results in cells that have epidermal thickening, inflammation, and COX-2 expression.

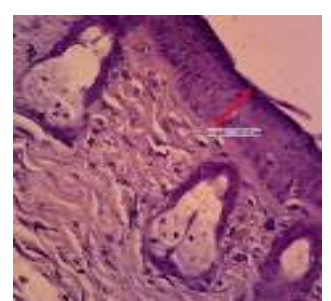

A1

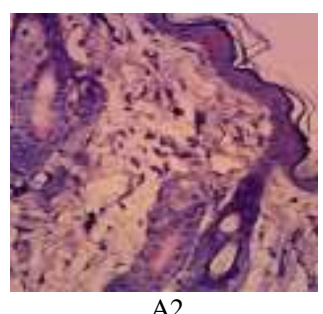

A2

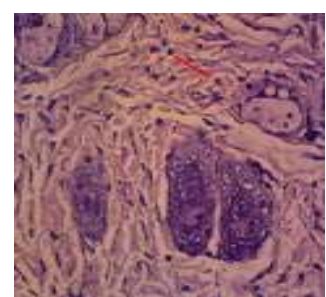

B1

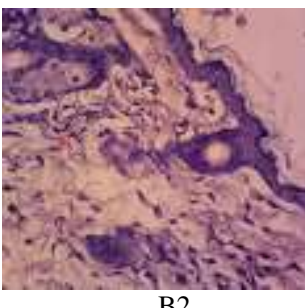

B2

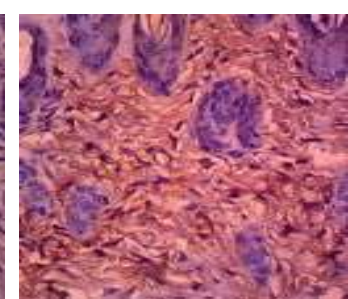

C1

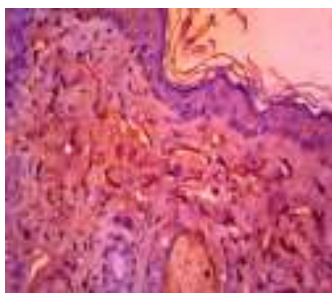

Figure 1. Miscroscopic section of skin tissues dyed using hematoxycilin-eosin (HE) (A) Epidermis thickness, (B) Anti-inflammatory cells and (C) Cells expressing COX-2 by immunohistochemical stain (1) Cream containing eel fish oil : sea cucumber 2:1 and (2) normal group 
Based on the microscopic view on Figure 1, and the thickness percentage of the epidermis, number of inflammatory cells, and cells expressing COX-2 as parameters from Table 3, the best antiinflammatory activity was found in the cream containing eel fish oil and sea cucumber extract with 2:1 ratio.

From those three parameters, it can be seen that EPA and DHA, which are the main ingredients of eel oil and sea cucumber extract, can increase anti-inflammatory activity. EPA and DHA will be carried through the edema plasma to the area with inflammation at the tissue level and converted enzymatically into resolvin, protectins, and maresins which are bioactive compounds for tissue inflammation and injured organ. The amount of resolvin, protectins, and maresin will increase along with increasing EPA and DHA intake into the body (Serhan, 2014). EPA and DHA regulate proinflammatory cytokine production, NF-kB transcription activity, and cytoplasmic signaling events (Mullen et al., 2010). The cream with a higher ratio of eel oil can increase the anti-inflammatory activity. The albumin content of eel is thought to increase the ability of EPA and DHA as antiinflammatory agents by balancing the osmotic pressure of cells so that swelling, which is one of the characteristics of inflammation, can be reduced (Haq et al., 2018; Putri et al., 2016).

\section{CONCLUSION}

Cream made of eel oil with sea cucumber extract with 2:1 ratio has the best anti-inflammatory activity based on inflammatory cell number reduction, epidermal thickness, and decreasing number of cells expressing COX-2 as parameters, for male white mice of BALB / C strain induced with croton oil.

\section{REFERENCES}

Ahn, J. C., Chong, W.-S., Na, J. H., Yun, H. B., Shin, K. J., Lee, K. W., \& Park, J. T. (2015). An Evaluation of Major Nutrients of Four Farmed Freshwater Eel Species (Anguilla japonica, A. rostrata, A. bicolor pacifica and A. marmorata). Korean Journal of Fisheries and Aquatic Sciences, 48(1), 44-50. https://doi.org/10.5657/kfas.2015.0044

Calder, P. C. (2013). Omega-3 polyunsaturated fatty acids and inflammatory processes: Nutrition or pharmacology? British Journal of Clinical Pharmacology, 75(3), 645-662. https://doi.org/10.1111/j.1365-2125.2012.04374.x

Garavito, R. M., \& Dewitt, D. L. (1999). The cyclooxygenase isoforms: Structural insights into the conversion of arachidonic acid to prostaglandins. Biochimica et Biophysica Acta-Molecular and Cell Biology of Lipids, 1441(2-3), 278-287. https://doi.org/10.1016/S1388-1981(99)00147-X

Haq, F. M., Santoso, H., \& Syauqi, A. (2018). Analisa kadar protein albumin ikan sidat ( Anguilla bicolor ) air tawar segar dan dikukus di Maduran Lamongan, e-Jurnal Ilmiah sains alami, 1(September),1: 13-19.

Janakiram, N. B., Mohammed, A., \& Rao, C. V. (2015). Sea cucumbers metabolites as potent anticancer agents. Marine Drugs, 13(5), 2909-2923. https://doi.org/10.3390/md13052909

Kitajima, M., Kimura, A., \& Suzuki, H. (2018). Cutting Edge: Nqo1 Regulates Irritant Contact Hypersensitivity against Croton Oil through Maintenance of Dendritic Epidermal T Cells. The Journal of Immunology, ji1701389. https://doi.org/10.4049/jimmunol.1701389

Kusharto, C. M., Emi Widyasari, R. A. H., Budywiryawan, B., Sri Wiyono, E., \& Sugengherisuseno, S. (2014). Nutritive value and fatty acids profile of fresh indonesian eel (Anguilla bicolor) and kabayaki. Jurnal Sains Kesihatan Malaysia, 12(1), 41-46. https://doi.org/10.17576/jskm-12012014-06

Lan, M., Wan, P., Wang, Z. Y., \& Huang, X. L. (2012). [GC-MS analysis of chemical components in seeds oil from Croton tiglium]. Zhong Yao Cai $=$ Zhongyaocai $=$ Journal of Chinese Medicinal Materials.

Lane, D. J. W., \& Limbong, D. (2015). Catastrophic depletion of reef-associated sea cucumbers: 
Resource management/reef resilience issues for an Indonesian marine park and the wider IndoPacific. Aquatic Conservation: Marine and Freshwater Ecosystems, 25(4), 505-517. https://doi.org/10.1002/aqc.2421

MacKay, D., \& Miller, A. L. (2003). Nutritional Support for Wound Healing. In Alternative Medicine Review.

Moore, B., \& Simmons, D. (2012). COX-2 Inhibition, Apoptosis, and Chemoprevention by Nonsteroidal Anti-inflammatory Drugs. Current Medicinal Chemistry, 7(11), 1131-1144. https://doi.org/10.2174/0929867003374273

Mullen, A., Loscher, C. E., \& Roche, H. M. (2010). Anti-inflammatory effects of EPA and DHA are dependent upon time and dose-response elements associated with LPS stimulation in THP-1derived macrophages. Journal of Nutritional Biochemistry, 21(5), 444-450. https://doi.org/10.1016/j.jnutbio.2009.02.008

Purwati, P. (2018). Reproductive patterns of holothuria scabra (Echinodermata: holothuroidea) in Indonesian waters. Marine Research in Indonesia, 30, 47-55. https://doi.org/10.14203/mri.v30i0.423

Putri, A. A. B., Yuliet, Y., \& Jamaluddin, J. (2016). Analisis kadar albumin ikan sidat (Anguilla marmorata dan Anguilla bicolor) dan uji aktivitas penyembuhan luka terbuka pada kelinci (Oryctolagus cuniculus). Jurnal Farmasi Galenika (Galenika Journal of Pharmacy) (e-Journal), 2(2), 90-95. https://doi.org/10.22487/j24428744.2016.v2.i2.5967

Sasongko, H., Efendi, N. R., Budihardjo, A., Farida, Y., Amartiwi, T., Rahmawati, A. A., Wicaksono, A., \& Sugiyarto. (2017). Solvent and extraction methods effects on the quality of eel (Anguilla bicolor) oil. Journal of Physics: Conference Series, 795(1). https://doi.org/10.1088/17426596/795/1/012021

Sasongko, H., Saputro, B. A., Hidayati, R. W. N., Raka, S. W. S., \& Sekarjati, T. A. (2018). The effect of hydrocarbon ointment containing eel fish (Anguilla bicolor bicolor) and snakehead fish (Channa striata) oil for wound healing in Wistar rats. AIP Conference Proceedings, 2019. https://doi.org/10.1063/1.5061899

Sasongko, Heru, Rahmawati, A. A., Kusumastuti, N. I., \& Alifa, G. R. (2019). in-Vivo Analgesic and Anti-Inflammatory Effects of Eel (Anguilla Bicolor Bicolor) Oil. Pharmaciana, 9(1), 59-70. https://doi.org/10.12928/pharmaciana.v9i1.9199

Serhan, C. N. (2014). Pro-resolving lipid mediators are leads for resolution physiology. Nature, 510(7503), 92-101. https://doi.org/10.1038/nature13479

Shah, B. N., Seth, A. K., \& Maheshwari, K. M. (2011). A review on medicinal plants as a source of anti-inflammatory agents. Research Journal of Medicinal Plant. https://doi.org/10.3923/rjmp.2011.101.115

Sugihartini, N., Saridewi, R., Ramdhani, U. M., Rahmawanti, F., Yuliani, S., \& Sophia, V. (2017). Anti-inflammatory Activity of Camellia sinensis, 1. Extract Cream Combined with Vitamin C as Antioxidant on Croton Oil-induced Inflamation in Male Mice Strain BALB/C Daya AntiInflamasi Krim Kombinasi Ekstrak Teh Hijau dan Vitamin C sebagai Antioksidan pa. Traditional Medicine Journal, 22(2):73-79.

Vors, C., Allaire, J., Marin, J., Lépine, M. C., Charest, A., Tchernof, A., Couture, P., \& Lamarche, B. (2017). Inflammatory gene expression in whole blood cells after EPA vs. DHA supplementation: Results from the ComparED study. Atherosclerosis, 257, 116-122. https://doi.org/10.1016/j.atherosclerosis.2017.01.025

Wen, J., Hu, C., \& Fan, S. (2010). Chemical composition and nutritional quality of sea cucumbers. Journal of the Science of Food and Agriculture, 90(14), 2469-2474. https://doi.org/10.1002/jsfa.4108

Whitehouse, M. W., \& Fairlie, D. P. (1994). Anti-Inflammatory activity of a holothurian (sea cucumber) food supplement in rats. Inflammopharmacology, 2(4), 411-417. https://doi.org/10.1007/BF02678607 
Wiranto, E., Wibowo, M. A., \& Ardiningsih, P. (2016). Aktivitas antiinflamasi secara in-vitro ekstrak teripang butoh keling (Holothuria leucospilota Brandt) dari Pulau Lemukutan. Jurnal Kimia Katulistiwa, 5(1), 52-57.

Yahyav. (2012). Fatty acid composition in two sea cucumber species, Holothuria scabra and Holothuria leucospilata from Qeshm Island (Persian Gulf). African Journal of Biotechnology, 11(12), 2862-2868. https://doi.org/10.5897/ajb11.3529 